Svetlana Ignjatijević ${ }^{1}$

Maja Cogoljević ${ }^{2}$

Nikola Milenković ${ }^{3}$
JEL: 043, I25, 015

DOI: 10.5937/industrija46-16126

UDC: $330.341: 37$

005.321:331.101.3

Case research

\title{
Economic Assessment of Significance of Education in the Development of a Knowledge-Based Economy
}

\author{
Article history: \\ Received: 25 December 2017 \\ Sent for revision: 16 January 2018 \\ Received in revised form: 13 July 2018 \\ Accepted: 8 August 2018 \\ Available online: 2 October 2018
}

\begin{abstract}
Research subject is an analysis of the role of education in development of a country, with a goal to look at all differences in views of examinees employed in the economy, educational institutions and students on the role of the government, economy and educational institutions in economic development. Research was conducted in Serbia, Croatia and Macedonia in 2014, by using a survey method. Research results have shown that there is a difference in opinions about the role of the public and private sector in education, depending on where examinee lives, while on the other hand difference in employment is not affecting the difference in their views. When the role of educational institutions and education itself is in question, research showed that there are no differences between Serbian, Croatian and Macedonian examinees. Although there is a difference between examinees according to their employment and it's the biggest between students, while there is no big difference between employed examinees.
\end{abstract}

Keywords: cross country analysis, education, economic growth, students, educational institutions

\section{Ekonomska ocena značaja obrazovanja u razvoju ekonomije zasnovane na znanju}

Apstrakt: Predmet istraživanja je analiza uloge obrazovanja u razvoju zemlje, sa ciljem da se sagledaju razlike u stavovima ispitanika zaposlenih u privredi,

\footnotetext{
${ }^{1}$ Faculty of Economics and Engineering Management in Novi Sad, svetlanacecaignjatijevic@gmail.com

${ }^{2}$ Faculty of Business Economics and Entrepreneurship

${ }^{3}$ School of Economics and Management Studies Kragujevac
} 
Ignjatijević S., et al: Economic Assessment of Significance of Education in the...

zaposlenih u obrazovnim institucijama i studenata o ulozi države, privrede $i$ obrazovnih institucija u razvoju ekonomije. Istraživanje je sprovedeno metodom ankete na području Srbije, Hrvatske i Makedonije u toku 2014. godine. Rezultati istraživanja ukazuju da po pitanju uticaja $i$ uloge javnog $i$ privatnog sektora prema obrazovanju postoje izvesne razlike među državama ispitanika, dok razlika u zaposlenju ne utiče na razliku u stavu. Kada je u pitanju uloga obrazovnih institucija i obrazovanja istraživanje je pokazalo da ne postoje razlike između ispitanika u Srbiji, Makedoniji i Hrvatskoj. Ipak razlika postoji između ispitanika prema zaposlenju i najizrazitija je kod studenata, dok među zaposlenima ne postoji značajna razlika u stavu.

Ključne reči: među državna analiza, obrazovanje, privredni rast, studenti, obrazovne institucije

\section{Introduction}

Economic growth and development depend on a number of factors such as, workforce, natural resources, savings, investment, education, research and innovation and technological progress. Today's population is certainly gaining importance. The reasons for that can be found in rapid progress and expansion of information and communication technologies (ICT), under whose influence the very fundaments of the industrial society are changing (Devetaković et al., 2009). The important question to answer is whether education advances with technological development (Barić, 2003). This means that education isn't a permanently acquired advantage, and there is always a need for permanent education. Improving knowledge and competences is justified through the need of harmonizing capabilities acquired by education and practice with requirements of the workplace. On one hand economics growth and technological progress of the society depend on the quality of human capital. On the other, human capital depends on the extent to which a state, economic subject, and certainly educational institutions recognize the importance of this triangle in directing economic development. There is a worrying fact that human capital in South-Eastern Europe (SEE) countries is decreasing, especially in: Serbia, Bosnia and Herzegovina, Macedonia and Croatia, due to long term emigration. A concerning fact is that human capital is practically disappearing. In a situation when it is underused or not used at all, and especially when the human capital isn't advanced, it behaves in an "identical way as the financial capital, it outflows into surroundings where it expects greater yield" (Cvetanović \& Despotović, 2014). As Ignjatijević, Raičević \& Đorđević (2011) indicated in earlier researches "education is in the function of human and sustainable development with calculated effects on the increase of labour productivity", and investment in education should be understood as investment into the 
Ignjatijević S., et al: Economic Assessment of Significance of Education in the...

future. That is why it is wrong to treat educational expenses as current, expenditures for prosperity and spending resources that decrease savings (Lutovac, 2009; Ruso et al., 2017; Hava \& Erturgut, 2010). It pays off to invest in education on an individual level, however economic viability of investing in education on a larger scale depends on the compatibility of educational institutions and the labour market, quality of acquired knowledge and the possibility to put that knowledge and skills to use (Pastuović, 2012). It is within this context that monitoring, promoting quality of education and establishing relations between investing, human capital and foreign capital is significant for international competitiveness and economic development. Formal contribution to the development of a knowledge-based society is achieved through adoption of state strategies for education development (latest adopted strategies for education were: Serbia - 2017, Macedonia -2018 and Croatia in 2014). This doesn't imply only a declarative commitment for creating a knowledge-based society, but reasoned opinions on the way in which this could be achieved and the type of support that the country will offer to the institutions involved in this type of development. The speed in accepting new strategies and raising the quality of human capital will significantly increase the speed of economic growth and its adaptation to the global economy (Zubović, 2010).

This research included Serbia, Macedonia and Croatia, which were federal units of a single country with singular educational system. Today these are independent countries: Croatia - a member of the EU, and Serbia and Macedonia which are in the process of obtaining membership in the EU. The region is marked with high migration of citizens, especially highly educated, with the differences in economic development are small. The mentioned countries were chosen due to abundance of similarities as well as differences, primarily in financing education and lack of comparative studies. The questions that arise are: Do Serbian, Macedonian and Croatian economies recognize the importance of quality of human resources; are they capable of financing and in what amount, an improvement in quality of human resources; how effectively can they prevent brain drain; do educational institutions appreciate needs and changes on the labour market, etc. Relying on previous researches in the mentioned countries, this study measures the attitudes of respondents in Serbia, Croatia and Macedonia on the role of education in economic development with the goal to look at the differences in attitudes of respondents employed in the economy, respondents employed in educational institutions and students, on the role of the country, economy and educational institutions. Comparing the similarities, i.e. differences in perceiving education, it's possible to observe the characteristics of each country. Implementing the education development strategy with regard to attitudes of relevant respondent groups will contribute to an increase of education's effect, creation of conditions for strengthening an economy, overcoming 
Ignjatijević S., et al: Economic Assessment of Significance of Education in the...

development disparities, increase in employment - in all, economic development of analysed countries.

\section{Literature Overview}

In modern conditions of economic activities, investment in knowledge, research and development is in direct connection with promoting efficiency of production. Modern economic theory argues that economic growth and development are based on development of human capital as a key production resource. Investment in education and promotion of health conditions of a population positively influences economic growth, movement of average productivity and real growth of earnings. Higher level of education implies higher level of rent, and this motivates people to get educated (Cvetanović \& Despotović, 2014; Glushak et al., 2015).

It is interesting to mention that researches of authors are directed at analysing the influence of education on economic growth.

Pokrajac (2001) indicated that in today's time, society of knowledge and knowledge economy have become known on a global scale, and are very popular terms. Đurović (2012) and Pana and Mosora (2013) point out that economy of the EU countries is based on knowledge, capable of maintaining dynamic economic growth with an increase and better paid workplaces. The importance of knowledge for development of the economic process is by Nijkamp and Siedschlag (2001) changed and today it is run by technological innovations (Baroo, 1991).

Sagi, Carayannis, Dasgupta and Thomas (2006) and Mercan and Sezer (2013) in the studies on the significance of ITC reveal that deep transformation of the world economy is stimulated by the process of globalization and supported by strong development of ITC. Drašković (2010) argues that knowledge economy influences, not only the creation of new products and technologies, as it is characterized by new organizational forms of businesses and management.

Addressing the development of knowledge economy and the level of development of the ICT sector, Krstić and Džunić (2013, p. 156) indicate that countries of Western Balkan are largely behind the EU countries. They have also pointed out that the level of development in the developed countries from the top of the KEI list is for us, nearly impossible to reach.

Krueger and Lindahl (2001) and Atalay (2015) are pointing out in their research, the role of education in economic growth. "A large research body using individual-level data on education and income provides robust evidence of substantial payoff to investment in education, especially for those who 
Ignjatijević S., et al: Economic Assessment of Significance of Education in the...

traditionally complete low levels of schooling“ (p. 1130). The authors have concluded that "cross-state regressions indicate that the change in education is positively associated with economic growth once measurement error in education is accounted for". They are of an opinion that countries which improve the educational system, are making an improvement in other policies with the goal of economic development.

Contrary to Benhabib and Spiegel's (1994) and Barro (1991) conclusions, cross-country regressions indicate that the change in education is positively associated with economic growth once measurement error in education is accounted for. Indeed, after adjusting for measurement error, the change in average years of schooling often has a greater effect in cross-country regressions than in the within-country micro regressions. The larger return to schooling found in the cross-country models suggests that there is a problem at the country level of analysis, or that increases in average educational attainment generate nationwide externalities (Ilić et al., 2016).

Cvetanović and Despotović (2014) point out that education influences economic and social development of certain communities as they say, contributes to promotion of different aspects: "democracy, civil rights, allocation of income, health, nutrition, reduction in poverty" (p. 3).

Lee (2001) and Kruss, McGrath, Petersen and Gastrow (2015) recognize knowledge as a key factor of competitiveness in the 21 st century and emphasize the role of information technologies and studying in economic development. The author analyses the role of knowledge in the process of transformation of the Korean economy towards a new economy based on knowledge. In accordance with the research of Afzal and Lawrey (2012), and studies of Derek, Chen and Dahlman (2005), the authors point to the significance and role of knowledge in long-term economic development. Authors refer to knowledge as the key initiator of economic growth and that development in education, innovation, information and communication technologies depends on economic and institutional surroundings.

In his study, Gabula (2012a) points out the attitude of students which is that, the existing educational systems offer very little practical and applicable knowledge. The author also reveals that conventional methods of studying imply a more significant usage of ICT. Sirková, Ali Taha, Ferencová and Šafárik (2014) argue a positive attitude of the employed to continuous studying and specialization. In this way the employed improve their working capabilities and achieve better results, develop their career and promote relations. According to them, the results achieved are significant for the organization as well. In her empirical study, Ferencová (2012) indicates the role of practical experiences in qualifying and preparing students for employment. A similar study was conducted by Gabula (2012b). The author researched a way in which education in India is adjusting to society's modern 
Ignjatijević S., et al: Economic Assessment of Significance of Education in the...

trends. They concluded that economic growth only partly depends on investment in production capacities, but that in the largest part, progress is achieved by investing in human potential.

The authors of the aforementioned studies used econometric models for measuring the influence of factors, macro indicators and educational characteristics on growth of GDP. Significant number of studies deal with the analysis of economy competitiveness index with an emphasis on educational competitiveness, knowledge economy index, i.e. they observe quantitative indicators. However it is significant to point out that the conducted analyses disregarded the attitudes and perception of individuals. Consequently, opposed to indices, percentages and budget expenditure for education, this paper focuses on the relationship of the state with all effects of education that are directed at individuals. Real contribution of the state, educational institutions and the economy to a knowledge-based economy doesn't only have a quantitative, but a qualitative value as well, through debt analysis of immeasurable or difficultly measurable factors of economic development, on the level of an individual. The contribution and specificity of this study is in the fact that the research starts at the level of an individual and ends with the economy as a whole.

\section{Research methodology}

The significance of education in economic development of the analysed countries is great, and indirect effects are measured in GDP, increase in employment, technological development and the like. The aim of this paper is to offer new findings on the significance of knowledge for promoting competitiveness of economies, i.e. the role of education in development of a knowledge-based economy. The research subject is significant for development of an economy considering the globalization process in education, i.e. integration in a singular European educational system. It's processed by using adequate scientific-research methods with relevant statistical methods. The paper started with an assumption that the structure of respondent attitudes in all of the three samples isn't significantly different, and thus a unified factor analysis was performed.

Factor analysis (Thompson, 2004) is a statistical technique that reduces the size of input variables. All similar and greatly interdependent variables are grouped together. The mentioned technique is used in order to discover the pattern of behaviour of used variables. The following steps are conducted in factor analysis: Correlation matrix - in this step, a correlation matrix between variables is constructed in order to obtain the ratio of two variables; Determining the number of latent factors - in order to determine the number of latent factors, several rules were used: own values must be larger than 1 , 
Ignjatijević S., et al: Economic Assessment of Significance of Education in the...

graphical Scree test and that the total variance amount must be over $75 \%$; Factor rotation - in order to interpret the results with more ease, Promax factor rotation; Factor loading matrix - for determining significance of factors.

After certain factor scores, it was examined whether there are differences in the significance of the role of the public or private sector and the benefits of education in different countries and between different groups of respondent employments. In order to determine this, two two-way variance analyses were conducted (ANOVA) with factor scores as dependent variables, and country and employment group as independent variables. Four respondents were excluded from the sample before the analysis because their scores significantly deviated from other respondent scores. Data was processed in statistical packet SPSS for Windows, version 22.

In the research participated 317 examinees from 3 countries - 99 from Serbia, 118 from Macedonia and 100 from Croatia. Through this research, the authors chose these countries because they were parts of a federal state. Croatia is now an EU member, Serbia is expecting to open negotiation chapters and Macedonia is at the beginning of that process.

These 3 countries have had the same educational system until recently, so it was important to consider how the expectations of examinees have changed. Within each country approximately an equal number of persons employed in the educational institutions, persons employed in non-educational institutions and students of social and natural sciences, were tested. The views of the respondents were tested by using a questionnaire for measuring the attitudes of respondents about the role of education in economic development. In the Questionnaire there are 36 questions, 3 of them dichotomous and 33 questions with a five degrees Likert scale. The respondents rated the level of agreement with the specified statements, with responses on a scale from 1 (strongly disagree, or not significantly, not required) to 5 (significantly or completely agree). Dichotomous questions were answered with "yes" or "no" depending on the agreement or disagreement with mentioned opinion. Questions are created to show the attitudes about the role of the state, economy and educational institutions, apropos education in country's economy. Research was conducted through a survey, where the degree of agreement of correspondent with stated findings is rated. The survey was anonymous, examinees were picked according to the "snowball" principle and it was filled out on-line.

\section{Results and discussion}

Research results point to the following: Kaiser-Meyer-Olkin measure of sample adequacy has a high value $(\mathrm{KMO}=.89)$ and Bartlett's test of 
Ignjatijević S., et al: Economic Assessment of Significance of Education in the...

sphericity is more significant $\left(X^{2}(528)=5210.82, p<.001\right)$ as we approached the analysis. Using the Cattells scree criteria two factors were withheld. To achieve a simple structure, factors were rotated via Promax rotation. Based on satiation in the assembly matrix and analysis of internal consistency of the survey, it was decided that 5 items should be excluded from further analysis, which had saturation below .30 and whose exclusion has increased the reliability coefficient. These items are: "Long-term unemployment is more dominant among people with low qualifications.", "The reforms of compulsory education are needed.", "It is necessary to reduce the workload of teachers and students, and put the emphasis on practically applicable knowledge.", "The Secondary Schools need a process of external quality audits." and "The Educational System is prepared for cooperation with the industry." These issues cannot be joined by any of the groups or factors. Repeated analysis with no critical items showed two factors (Cattell's scree criterion), which are rotated in Promax rotation, and together account for $45.95 \%$ of the variance. The extracted factors are moderately positively correlated $(r=.54, p<.001)$, and the reliability coefficient for the questionnaire as a whole is 93 .

Taking into consideration the saturation shown in the assembly matrix (Table 1), the given factors were interpreted i.e. grouped into two wholes: first factor - Role and relation of the public and private sector to education, and the second factor - Role of educational institutions and benefits from education.

Table 1. Assembly matrix of the given factor solution

\begin{tabular}{|c|c|c|}
\hline \multirow{2}{*}{ Item } & \multicolumn{2}{|c|}{ Factor } \\
\cline { 2 - 3 } & $\begin{array}{c}\text { Role and relation of } \\
\text { the public and } \\
\text { private sector to } \\
\text { education }\end{array}$ & $\begin{array}{c}\text { Role of educational } \\
\text { institutions and } \\
\text { benefits from } \\
\text { education }\end{array}$ \\
\hline $\begin{array}{c}\text { The State recognizes education as an important } \\
\text { factor of economic development and increase of } \\
\text { competitiveness of the industry. }\end{array}$ & .835 & \\
\hline $\begin{array}{c}\text { The State supports the concept of lifelong } \\
\text { learning. }\end{array}$ & .825 & \\
\hline $\begin{array}{c}\text { The State allocates sufficient funds for } \\
\text { education. }\end{array}$ & .783 & \\
\hline $\begin{array}{c}\text { The State encourages the acquisition of IT skills } \\
\text { in the society. }\end{array}$ & .756 & \\
\hline $\begin{array}{c}\text { The State encourages entrepreneurship and } \\
\text { supports the most creative authors. }\end{array}$ & .736 & \\
\hline $\begin{array}{c}\text { The State has created the conditions for e- } \\
\text { business. }\end{array}$ & .736 & \\
\hline $\begin{array}{c}\text { The State stimulates education through fiscal } \\
\text { measures. }\end{array}$ & .698 & \\
\hline $\begin{array}{c}\text { The State puts significant efforts to prevent the } \\
\text { emigration of young people and scientists } \\
\text { abroad. }\end{array}$ & .696 & \\
\hline The State supports international cooperation & .684 & \\
\hline
\end{tabular}


Ignjatijević S., et al: Economic Assessment of Significance of Education in the...

\begin{tabular}{|c|c|c|}
\hline \multirow[b]{2}{*}{ Item } & \multicolumn{2}{|c|}{ Factor } \\
\hline & $\begin{array}{l}\text { Role and relation of } \\
\text { the public and } \\
\text { private sector to } \\
\text { education }\end{array}$ & $\begin{array}{l}\text { Role of educational } \\
\text { institutions and } \\
\text { benefits from } \\
\text { education }\end{array}$ \\
\hline \multicolumn{3}{|l|}{ and specialization in the field of education. } \\
\hline $\begin{array}{c}\text { The State recognizes education as a public } \\
\text { interest. }\end{array}$ & .641 & \\
\hline $\begin{array}{l}\text { Employers are systematically encouraged to } \\
\text { improve the educational structure of employees. }\end{array}$ & .527 & .323 \\
\hline $\begin{array}{c}\text { Companies in the industry believe that it is in } \\
\text { their own interest to improve the quality of the } \\
\text { education system. }\end{array}$ & .450 & .359 \\
\hline $\begin{array}{l}\text { The Public Sector of the economy devotes high } \\
\text { attention to the high competence employees. }\end{array}$ & .447 & \\
\hline $\begin{array}{l}\text { The Public Sector in the State encourages the } \\
\text { improvement of the education of its employees. }\end{array}$ & .440 & .409 \\
\hline $\begin{array}{l}\text { Educational institutions encourage the } \\
\text { specialization of their employees. }\end{array}$ & .439 & .403 \\
\hline $\begin{array}{c}\text { The Private Sector in the state encourages the } \\
\text { improvement of the education of their } \\
\text { employees. }\end{array}$ & .432 & \\
\hline $\begin{array}{c}\text { In a society there is an opinion that the } \\
\text { education helps improving the material status } \\
\text { and the quality of life. }\end{array}$ & .414 & \\
\hline $\begin{array}{l}\text { Schools and faculties have adequate spatial } \\
\text { capacities and adequate equipment for quality } \\
\text { teaching. }\end{array}$ & .351 & \\
\hline $\begin{array}{l}\text { Secondary education system adequately } \\
\text { prepares young people for the labour market or } \\
\text { the continuation of education. }\end{array}$ & .339 & \\
\hline $\begin{array}{l}\text { Educated workforce has a positive impact on } \\
\text { attracting investments. }\end{array}$ & & .892 \\
\hline $\begin{array}{l}\text { Knowledge and skills have an impact on } \\
\text { increasing work productivity. }\end{array}$ & -.338 & .860 \\
\hline $\begin{array}{l}\text { Knowledge and skills improve profitability and } \\
\text { job security. }\end{array}$ & & .807 \\
\hline $\begin{array}{l}\text { The companies with the professionals have the } \\
\text { best business results. }\end{array}$ & & .774 \\
\hline $\begin{array}{c}\text { The Private Sector of the economy devotes } \\
\text { close attention to the high competence } \\
\text { employees. }\end{array}$ & & .640 \\
\hline $\begin{array}{l}\text { Higher Education is associated with better } \\
\text { employment prospects and high incomes. }\end{array}$ & & .536 \\
\hline $\begin{array}{l}\text { The Education System is focused on meeting } \\
\text { the individual needs. }\end{array}$ & & .420 \\
\hline $\begin{array}{c}\text { Talented individuals are supported by the } \\
\text { system as powerful holders of economic } \\
\text { development. }\end{array}$ & .399 & .411 \\
\hline $\begin{array}{c}\text { The quality of the education system is important } \\
\text { for the continuation of education and reducing } \\
\text { school leaving. }\end{array}$ & & .408 \\
\hline
\end{tabular}

Source: Author's calculation based on survey

Industrija, Vol.46, No.3, 2018 
Ignjatijević S., et al: Economic Assessment of Significance of Education in the...

When the Role and relation of the public and private sector in education are in question, the conducted analysis has shown significant effects of both factors, as well as marginally significant effect of their interaction. These results are shown in Table 2.

Table 2. Results of the variance analysis with the factor (Role and relation of the public and private sector to education and factor Role and relation of the public and private sector to education as dependent variables)

\begin{tabular}{|cccc|}
\hline \multicolumn{4}{|c|}{ Role and relation of the public and private sector to education } \\
\hline Effect & $\mathrm{F}(\mathrm{df} 1, \mathrm{df} 2)$ & $\mathrm{P}$ & $\eta 2$ \\
\hline State & $29.96(2,304)$ & .000 & .165 \\
Group of employment & $11.47(2,304)$ & .000 & .070 \\
$\begin{array}{c}\text { State } \times \text { Group of } \\
\text { employment }\end{array}$ & $2.11(4,304)$ & .080 & .027 \\
\hline Role of educational institutions and benefits from education & \\
\hline Effect & $\mathrm{F}(\mathrm{df} 1, \mathrm{df})$ & $\mathrm{P}$ & $\eta 2$ \\
\hline State & $0.47(2,304)$ & .624 & .003 \\
Group of employment & $6.35(2,304)$ & .002 & .040 \\
State $\times$ Group of & $1.35(4,304)$ & .253 & .017 \\
employment & & & \\
\hline
\end{tabular}

Source: Author's calculation

In the case of the factor Role of educational institutions and benefits from education, the analysis has only shown a significant effect of the factor Group of employment (Table 2, Figure 1). The conclusion is that in Role of educational institutions and benefits from education, a significant difference cannot be found between countries, while differences are visible between groups of employment. Further comparison with the LSD test has pointed that the factor Role of educational institutions and benefits from education is significantly expressed in the group of students $(M=0.30, S D=0.99)$, rather than in the group of employed in education $(M=-0.17, S D=0.79, p=.000)$ and the group employed outside educational institutions $(\mathrm{M}=0.02, \mathrm{SD}=1.02$, $p=.032$ ), while there wasn't a significant difference between the expression of the factor Role of educational institutions and benefits from education, between these two groups $(p=.137)$.

When we talk about the factor Role and relation of the public and private sector in education, even though the obtained interaction is marginally significant, it deserves attention and interpretation. There is a difference in the expression of the factor Role and relation of the public and private sector to education in the Serbian sample, between students and employed in noneducation institutions (it is more expressed in students), while the employed in education don't differ neither from students, nor the employed in other institutions. The situation is somewhat different in Macedonia, as there is no difference between students and the employed in educational institutions, while for the employed in other institutions this factor is less expressed than in 
Ignjatijević S., et al: Economic Assessment of Significance of Education in the...

first two groups. Finally, in Croatia the situation is completely different, as the employed who work in education and those who work outside it don't differ between each other, but they do differ from the student group - for students this factor is more expressed than in other two groups (Appendix 1).

Figure 1. Effect of interaction of state and group on the factor Role and relation of the public and private sector to education.

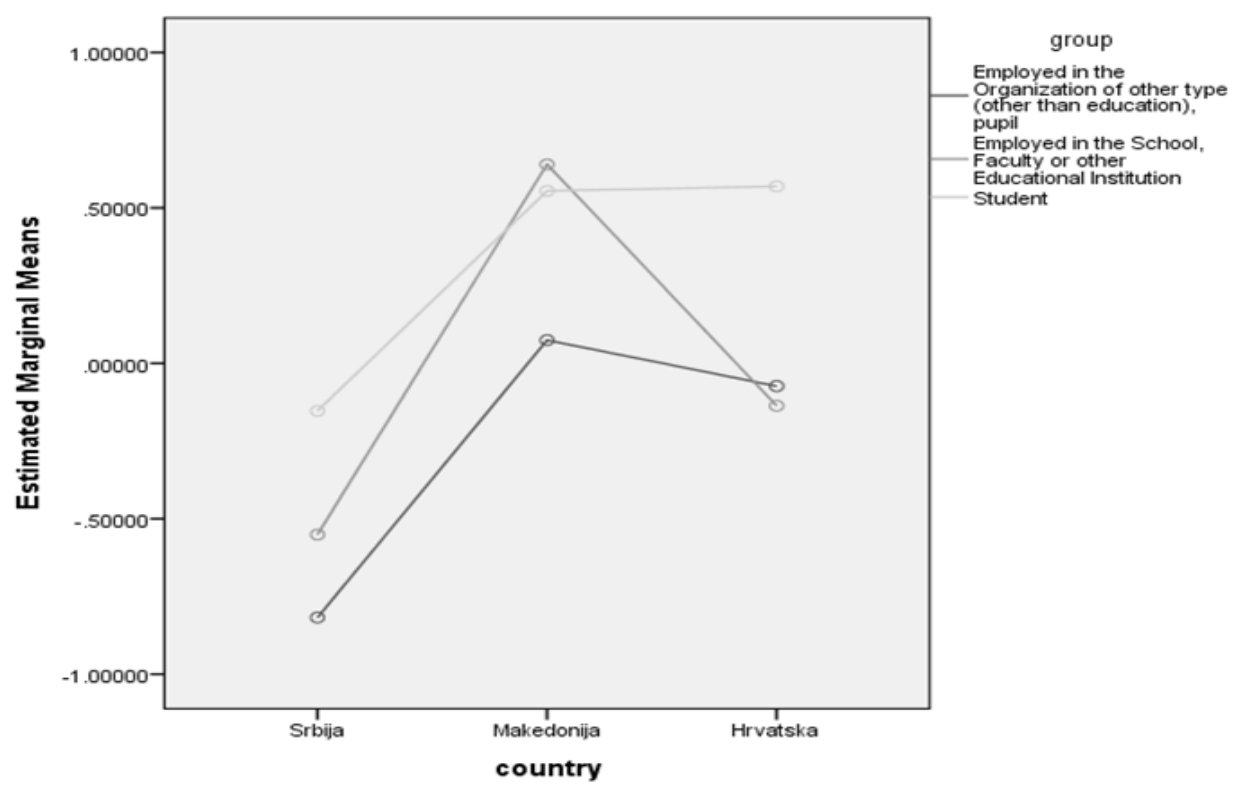

Source: author's research

Research results are shown in Figure 1 and have only partly confirmed the authors' expectations. Students have had a severely expressed attitude on the question of the role of the public and private sector, in all three countries. Analysing the attitudes which were attached to that factor, it is concluded that students expect a significant financial support from the state and investment in education, than for the state to invest efforts in preventing outflow of experts abroad. The authors' opinion is that students highly believe in the importance of education and their involvement in the education system. The concerning factor is the low level of attitude expression of the employed in the public sector and the economy in Serbia, which is significantly lower than in other countries. When the situation in Croatia is in question, the attitude of students is very strong and far from that of the employed, including the employed in education and non-education institutions. 
Ignjatijević S., et al: Economic Assessment of Significance of Education in the...

Table 3. Test statistics in questions of dichotomous type

\begin{tabular}{|c|c|c|c|c|c|c|}
\hline \multicolumn{7}{|c|}{ Test Statistics } \\
\hline & \multicolumn{2}{|c|}{$\begin{array}{l}\text { There is a synergy } \\
\text { between the } \\
\text { companies in the } \\
\text { industry and the } \\
\text { educational } \\
\text { institutions in the } \\
\text { development of } \\
\text { joint educational } \\
\text { programs }\end{array}$} & \multicolumn{2}{|c|}{$\begin{array}{l}\text { The Secondary } \\
\text { Schools and the } \\
\text { Faculties are } \\
\text { adapting to the } \\
\text { requirements of } \\
\text { the labour market } \\
\text { and they changing } \\
\text { and specializing } \\
\text { their programs in } \\
\text { accordance with } \\
\text { the needs of the } \\
\text { economy }\end{array}$} & \multicolumn{2}{|c|}{$\begin{array}{l}\text { Higher education } \\
\text { reforms in } \\
\text { accordance with } \\
\text { the Bologna } \\
\text { Declaration have } \\
\text { contributed to } \\
\text { improving the } \\
\text { quality of higher } \\
\text { education }\end{array}$} \\
\hline Frequencies & $\begin{array}{l}\text { Yes } \\
68\end{array}$ & $\begin{array}{c}\text { No } \\
249\end{array}$ & $\begin{array}{l}\text { Yes } \\
75\end{array}$ & $\begin{array}{l}\text { No } \\
242\end{array}$ & $\begin{array}{c}\text { Yes } \\
98\end{array}$ & $\begin{array}{c}\text { No } \\
219\end{array}$ \\
\hline $\begin{array}{c}\text { Chi-Square } \\
\text { Df } \\
\text { Asymp. Sig. }\end{array}$ & \multicolumn{2}{|c|}{$\begin{array}{c}103.347 a \\
1 \\
.000\end{array}$} & \multicolumn{2}{|c|}{$\begin{array}{c}87.978 a \\
1 \\
, 000\end{array}$} & \multicolumn{2}{|c|}{$\begin{array}{c}46.186 a \\
1 \\
, 000\end{array}$} \\
\hline
\end{tabular}

Source: Author's calculation

The results shown in Table 3 show the differences in the examinees' answers to dichotomous questions. The results confirmed that there is no difference in frequencies of answers to dichotomous question between states. Frequencies of responses point to a conclusion whether the examinees have considerably more used "no" as an answer. The results reveal that there are differences in frequencies of answers to all three dichotomous questions. This means that the examinees consider that there is no synergy between educational institutions and the economy during development of study programs. Most of the examinees no matter what country, consider that high schools and faculties don't adjust to the needs of the market and the economy and don't offer specialized programs, as well that the Bologna process doesn't contribute to the improvement of quality of high education.

\section{Conclusion}

Human capital is simultaneously the result of a production process and technological progress, and as such directly influences the growth rate. The market should serve with the aim to promote competitiveness of the human capital because it is the place where supply and demand come in relation, and with them labour. Situation on the market is characterized with significant flaws and limiting factors and the analysed countries are differentiated by the way in which they can successfully deal with all those problems. Development of a knowledge-based economy isn't an accidental product of the state, companies and educational institutions, but a result of accumulating and expanding knowledge and with that positive spill-over effects. 
Ignjatijević S., et al: Economic Assessment of Significance of Education in the...

Research results have confirmed that there are two groups, i.e. obtained factors are grouped in two wholes. The first factor - The role and relation of the public and private sector towards the education, and the second factor The role of educational institutions and the benefits of education. Results of the research are indicating that in terms of the impact of role of the public and private sector on education, there are certain differences between examinee's countries, while difference in employment is not affecting the differences in opinions.

When the Role of educational institutions and education is in question, the research has pointed that there aren't significant differences between the examinees in Serbia, Macedonia and Croatia. However, there is a difference between examinees according to employment and it is most expressed in students, while there isn't a significant difference in attitude for employees. Students have the most positive attitude towards education, which indicates high dedication to promoting competences and high level of awareness of education benefits. Youth is aware that education leads to higher employability, better workplace, greater earning and especially the possibility of employment abroad. Limited employment possibility in the real sector (for example in Serbia) is associated with unstimulating reward and promotion system in the public sector. After the education process ends and individuals are included in the work environment, further education is slowed down due to inadequately developed lifelong learning system, reverse, permanent and informal education. The employed have little chance of promotion in the workplace which certainly influences a change in attitude on the importance of educational institutions and education. The research has confirmed the differences in attitudes of students and employees in non-educational institutions (it's more pronounced in students) on the question of the role of the public and private sector towards education, on a sample in Serbia. The employed in the economy have the lowest expressed attitude. In Macedonia the situation is somewhat different. The employed in educational institutions and students have an expressed attitude on the role of the state and economy. A significantly lower attitude is expressed by the employed in the public and private sector of the economy. Finally, in Croatia the situation is completely different. Students in Croatia and Macedonia have almost the same degree of attitude expression. However, the attitude of all the employed is significantly lower in relation to students.

In the interest of long-term promotion of the situation of individuals and the economy as a whole it's necessary to encourage educational spending and scientific technological development. Investment in the workforce and employee education will harmonize technological changes and job needs. Considering the quality of educational system influences the quality of human resources, training and the ability to acquire new knowledge and skills, higher inflow of FDI would enable higher interaction between educational institutions 
Ignjatijević S., et al: Economic Assessment of Significance of Education in the...

and companies. Development of educational infrastructure with higher involvement of qualified teachers and greater use of innovative training and teaching methods in combination with practical experience would facilitate the creation and commercial use of knowledge. It's necessary to prevent the outflow of highly educated work force, increase the number of college educated individuals and promote the training system. Investment in the development of research centres would increase the number of researchers and contribute to an increase in cooperation of higher education sector and the economy.

And finally the question of common conclusion on the conducted research is raised. The research confirms the opinion that investment in education contributes to the economic growth of a country and welfare of individuals.

\section{References}

Afzal, M.N.I., \& Lawrey, R. (2012). Knowledge-based Economy (KBE) Frameworks and Empirical Investigation of KBE Input-output Indicators for ASEAN. International Journal of Economics and Finance, 4(9), doi:10.5539/ijef.v4n9p13

Atalay, R. (2015). The Education and the Human Capital to Get Rid of the Middleincome Trap and to Provide the Economic Development. Procedia - Social and Behavioral Sciences, 174, 969-976. doi:10.1016/j.sbspro.2015.01.720

Barić, V. (2003). Temeljne odrednice investiranja u obrazovanje odraslih. Pomorski zbornik, 41(1), 361-379.

Barro, R.J. (1991). Economic Growth in a Cross Section of Countries. The Quarterly Journal of Economics, 106(2), 407. doi:10.2307/2937943

Benhabib, J., \& Spiegel, M.M. (1994). The role of human capital in economic development evidence from aggregate cross-country data. Journal of Monetary Economics, 34(2), 143-173. doi:10.1016/0304-3932(94)90047-7

Cvetanovic, S., \& Despotovic, D. (2014). Knowledge as the component of human capital in economic growth models. Skola biznisa, 1, 1-17. doi:10.5937/skolbiz15976

Derek, H., Chen, C., \& Dahlman, C.J. (2005). The knowledge economy, the KAM methodology and World Bank operations. World Bank Institute Working Paper, No. 37256, Available at SSRN: http://ssrn.com/abstract $=841625$ (accessed on 1012 2014)..

Devetakovic, S., Gavrilovic, J.B., \& Rikalovic, G. (2009). National economy. Belgrade: Faculty of Economics.

Draskovic, M. (2010). Knowledge as an unlimited resource and facility management. Montenegrin Journal of Economics,11, 83-90. Available online: URL http://www.repec.mnje.com/mje/2010/v06-n11/mje_2010_v06-n11-a17.pdf (accessed on 211 2015)..

Djurovic, G. (2012). The European Union and Montenegro - enlargement policy. Pogorica: APPrint. 
Ignjatijević S., et al: Economic Assessment of Significance of Education in the...

Ferencová, M. (2012). An Analytical View of Communication and Managerial Capabilities and Their Use in Practice: Book Review. Polish Journal of Management Studies, 6(1), 241-242. Available online: http://www.pjms.zim.pcz.pl/files/AN-ANALYTICAL-STUDY-ONORGANIZATIONAL-CREATIVITY-IMPLICATIONS-FOR-MANAGEMENT.pdf (accessed on 1212 2016).

Gabula, A. (2012). Challenges with Curricula in Management Education. Journal of Applied Management and Investments, 1(2), 160-168. Available online: http://www.jami.org.ua/abstracts1-2.htm (accessed on 1012 2015)..

Gabula, A. (2012). Experiential Learning in Management Education. Journal of Applied Management and Investments,1(3), 319-325. Available online: http://www.jami.org.ua/abstracts1-3.htm (accessed on 1212 2015)..

Glushak, N., Katkow, Y., Glushak, O., Katkowa, E., \& Kovaleva, N. (2015). Contemporary Economic Aspects of Education Quality Management at the University. Procedia - Social and Behavioral Sciences, 214, 252-260. Paper presented at the Worldwide trends in the development of education and academic research, Sofia, Bulgaria. doi:10.1016/j.sbspro.2015.11.643

Hava, H., \& Erturgut, R. (2010). An evaluation of education relations together with technology, employement and economic development components. Procedia Social and Behavioral Sciences, 2(2), 1771-1775. 2(2): 1771-1775. doi:10.1016/j.sbspro.2010.03.982

Ilic, B., Praca, N., \& Kolarski, I. (2016). Modern Economic and Political Aspects of the New World Order. Oditor, 2(3), 49-62, UDK: 330.341:327(100).

Ignjatijevic, S., Raicevic, V., \& Djordjevic, D. (2011). Influence of environment on the competitiveness of education in the economic development of Serbia. Pedagogical reality, 57(5-6); 539-547.

Krstic, B., \& Dzunic, M. (2013). Knowledge economy and the competitiveness of the Western Balkans in the global economic crisis. Teme, 37(1), 141-162. Available online: http://teme2.junis.ni.ac.rs/public/journals/1/previousissues/teme12013/teme\%201-2013-07\%20lat.pdf (accessed on 512 2016)..

Krueger, A.B., \& Lindahl, M. (2001). Education for Growth: Why and for Whom. Journal of Economic Literature, 39(4), 1101-1136. doi:10.1257/jel.39.4.1101

Kruss, G., McGrath, S., Petersen, I., \& Gastrow, M. (2015). Higher education and economic development: The importance of building technological capabilities. International Journal of Educational Development, 43, 22-31. doi:10.1016/j.ijedudev.2015.04.011

Sang, K.L. (2001). Economic development through knowledge creation-the case of Korea. In Proceedings of the 34th Annual Hawaii International Conference on System Sciences. (p. 7). Institute of Electrical and Electronics Engineers (IEEE). doi:10.1109/hicss.2001.927139

Lee, K. S. (2001). Economic development through knowledge creation- the case of Korea, 34th Hawaii International Conference on System Science, Maui, Hawaii. Danvers: IEEE Computer Society, or the Institute of Electrical and Electronics Engineers, Inc. doi:10.1109/HICSS.2001.927139

Lutovac, M. (2009). Education and health care expenses in European Union member states and in the Republic of Serbia. International politics, 40 (1133); 84-90. 
Ignjatijević S., et al: Economic Assessment of Significance of Education in the...

Mercan, M., \& Sezer, S. (2014). The Effect of Education Expenditure on Economic Growth: The Case of Turkey. Procedia - Social and Behavioral Sciences, 109, 925-930. doi:10.1016/j.sbspro.2013.12.565

Nijkamp, P., \& Siedschlag, I. (2011). Innovation, growth and competitiveness: Dynamic regions in the knowledge-based world economy. Springer Science \& Business Media. doi: 10.1004/978-3-642-14964-1..

Pana, M., \& Mosora, C. (2013). From Quantity to Quality in Addressing the Relationship Between Education and Economic Development. Procedia - Social and Behavioral Sciences, 93, 911-915. doi:10.1016/j.sbspro.2013.09.302

Pastuović, N. (2012). Obrazovanje i razvoj: kako obrazovanje razvija ljude i mijenja društvo, a kako društvo djeluje na obrazovanje. Institut za društvena istraživanja u Zagrebu. Available online: https://www.idi.hr/images/stories/publikacije/SIP 198/prikaz 111 114.pdf

Pokrajac, S. (2001). Change management and management changes. Belgrade: Topy.

Ruso, J., Filipovic, J., \& Pejovic, G. (2017). The Role of Higher Education in National Quality Infrastructure Policy-Making. Management: Journal of Sustainable Business and Management Solutions in Emerging Economies, 22(1), 15-24. doi:10.7595/management.fon.2017.0003

Sagi, J., Carayanis, E., Dasgupta, S., \& Thomas, G. (2006). Globalization and ECommerce: A Cross-Cultural Investigation of User Attitudes. In G.M. Hunter \& F.B. Tan (Eds.), Advanced Topics in Global Information Management. (pp. 128148). Hershey, PA: IGI Global. doi:10.4018/978-1-59140-923-6.ch006

Sirková, M., Ali, T.V., Ferencová, M., \& Šafárik, P.J. (2014). An analytical study on organizational creativity: implications for management. Polish Journal of Management Studies, 0(2), 179-187. Available online: http://www.pjms.zim.pcz.pl/files/AN-ANALYTICAL-STUDY-ON.

Shakiba, M., Ale, E.N., Danaee, M., Bakhtiyari, K., \& Sundararajan, E. (2015). A Comprehensive Comparison of Educational Growth within Four Different Developing Countries between 1990 and 2012. Revista de Gestão e Secretariado, 6(3), 152-174. doi:10.7769/gesec.v6i3.486

Thompson, B. (2004). Exploratory and confirmatory factor analysis: Understanding concepts and applications. American Psychological Association.

Zubović, J. (2010). Razvoj privrede zasnovan na ulaganjima u ljudske resurse $i$ stranim investicijama. Institut ekonomskih nauka, Beograd. 